\title{
ANALISA FAKTOR KEPUASAN PENGHUNI APARTEMEN MENENGAH BAWAH DI SURABAYA
}

\author{
Kevin Harsono ${ }^{1}$, Timoticin Kwanda ${ }^{2}$, dan Jani Rahardjo ${ }^{3}$
}

\begin{abstract}
ABSTRAK: Maraknya apartemen di Surabaya tidak dapat dipisahkan dari keterbatasan lahan, serta harga landed house yang semakin meningkat. Akibatnya, pengembang harus menyusun strategi untuk mendapatkan minat beli konsumen. Untuk memenangkan persaingan, pengembang harus memberikan kepuasan kepada konsumen, baik dengan pelayanan, maupun dari konsep hunian. Proyek dapat dikatakan berhasil apabila produk yang dihasilkan memberikan tingkat kepuasan yang tinggi dari konsumen. Kepuasan penghuni didapat apabila harapan penghuni sama dengan kenyataan. Penelitian ini bertujuan untuk menganalisa faktor yang mempengaruhi kepuasan. Terdapat 4 faktor yang diuji dalam penelitian ini, yaitu aksesibilitas, desain bangunan, pemeliharaan dan operasional, serta kualitas pelayanan. Hasil penelitian menunjukan terdapat kesenjangan antara tingkat kepentingan dan kepuasan penghuni, sehingga kepuasan penghuni belum tercapai. Selain itu tidak terjadi perbedaan yang signifikan antara kepuasan penghuni terhadap lama menghuni. Faktor yang memerlukan perhatian khusus adalah pemeliharaan dan operasional, dimana terdapat gap antara tingkat kepuasan dan kepentingan. Strategi kombinasi ekspansi dan stabilitas diperlukan untuk meningkatkan kepuasan penghuni.
\end{abstract}

Kata kunci : kepuasan penghuni, faktor-faktor, apartemen menengah - bawah, strategi

ABSTRACT: Increasing demand of apartments in Surabaya can not be separated from land limitation and increasing price of landed house. As result, developers must have strategy to get consumer buying interest. To win the competition, developer must give satisfaction to the consumers, either with service, and building concept. The project can be said to succeed If the resulting product provides a high level of satisfaction from consumers. The satisfaction of the occupants is obtained when the residents' expectations are the same as the reality. This study aims to analyze the factors that affect satisfaction. There are 4 factors tested in this research, namely accessibility, building design, maintenance and operational, and service quality. The results showed there is a gap between the level of interest and satisfaction, so the satisfaction of residents has not been achieved. In addition, there is no significant difference between the satisfaction of residents to duration of inhabit. Factors that require special attention are maintenance and operations, where there is a gap between the level of satisfaction and importance. Combination strategy between expansion and stability are needed to improve occupant satisfaction.

Keywords: Residence Satisfaction, factors, midle low income apartment, strategy

\footnotetext{
${ }^{1}$ Mahasiswa Program Studi Magister Teknik Sipil Universitas Kristen Petra, kevinharsono.92@gmail.com

${ }^{1}$ Dosen Program Studi Magister Teknik Sipil Universitas Kristen Petra, cornelia@petra.ac.id

${ }^{1}$ Dosen Program Studi Magister Teknik Sipil Universitas Kristen Petra, jani@petra.ac.id
} 


\section{PENDAHULUAN}

Jumlah penduduk yang semakin meningkat berbanding lurus dengan kebutuhan akan tempat tinggal yang layak. Hal ini tidak sejalan dengan ketersediaan lahan di kota. Harapan untuk mendapatkan hunian landed house di daerah tengah kota semakin menipis dikarenakan harga tanah yang melambung tinggi dan semakin naik tiap tahunnya. Bagi masyarakat yang ingin memiliki landed house dengan harga yang relatif lebih rendah, banyak tersedia di luar pusat kota. Namun, bagi masyarakat yang ingin memiliki hunian di daerah tengah kota dengan harga yang relatif rendah, maka salah satu alternatif yang ada adalah hunian vertikal ataupun yang biasa disebut apartemen. Banyaknya proyek apartemen yang menjamur di berbagai daerah di Indonesia, termasuk di Surabaya merupakan fenomena yang menunjukan bahwa hunian vertikal semakin diminati (Coliers International, 2015). Maraknya proyek apartement di Surabaya, membuat pengembang harus memiliki strategi untuk mendapatkan minat beli konsumen terhadap produk yang dijualnya. Untuk memenangkan persaingan, pengembang harus mampu memberikan kepuasan kepada konsumen nya, baik dengan pelayanan, maupun dari segi konsep hunian (Sutanto, 2008).

Kepuasan penghuni merupakan salah satu tolak ukur pengembang dalam menentukan keberhasilan suatu proyek. Proyek dapat dikatakan berhasil apabila produk yang dihasilkan memberikan tingkat kepuasan yang tinggi dari konsumen. Kepuasan penghuni adalah respon penghuni terhadap evaluasi ketidak sesuaian antara tingkat kepentingan atau harapan yang dirasakan sebelumnya dan kinerja aktual yang dirasakan setelah pemakaian (Prasojo, 2014). Kepuasan penghuni dapat tercapai apabila harapan akan bangunan sama dengan yang didapat dan dirasakan oleh penghuni (Hadi, 2015), dimana tingkat harapan pada penelitian ini diwakilkan oleh tingkat kepentingan. Menurut Lara dan Bakker (2012), mengukur kepuasan penghuni tidaklah mudah dan sangat dinamis. Kepuasan penghuni sangat bergantung pada latar belakang, pengalaman serta kebutuhan personal sang penghuni membuat model kepuasan penghuni hampir mustahil dilakukan, mengingat banyaknya keterbatasan dalam pengkuran kepuasan penghuni. Namun dalam penelitian ini kepuasan penghuni menggunakan empat faktor utama, yaitu Aksesibilitas, Desain Bangunan, Pemeliharaan dan Operasional, serta Kualitas Pelayanan. Kepuasan penghuni tidak dapat dilepaskan dari strategi yang digunakan oleh peusahaan (Haryanto, 2013). Oleh sebab itu, untuk meningkatkan kepuasan penghuni apartemen menengah bawah di Surabaya diperlukan suatu strategi, dimana pada akhirnya, baik pengembang maupun pihak - pihak yang terkait dapat menggunakan hasil penelitian ini sebagai acuan untuk peningkatan kinerja serta acuan untuk pengembangan yang selanjutnya.

\section{TINJAUAN PUSTAKA}

\subsection{Kepuasan Penghuni}

Wardani (2001) menyatakan bahwa kepuasan konsumen dapat digambarkan sebagai rasio antara kualitas yang diterima dengan kebutuhan, keinginan, dan harapan konsumen. Menurut Sari (2007), kepuasan adalah keadaan pasca konsumsi, dimana suatu produk yang dipilih setidaknya memenuhi atau melebihi harapan, dimana dapat diukur dengan membandingkan kinerja atau hasil yang dirasakan dengan harapan. Pengukuran kepuasan penghuni adalah satu cara menentukan seberapa jauh sebuah rumah atau apartemen dapat memenuhi kebutuhan dan harapan penghuni (Wiesenfeld, 1992). Berdasarkan studi literatur yang dilakukan oleh peneliti, maka ditentukan empat variabel utama sebagai faktor yang mempengaruhi kepuasan penghuni apartemen, yaitu Aksesibilitas, Desain Bangunan, Pemeliharaan dan Operasional, serta Kualitas layanan. Masing - masing variabel nantinya akan diuraikan lebih detail berdasarkan indikator-indikator yang mempengaruhinya(Tabel 1) 
Tabel 1. Faktor Kepuasan Penghuni

\begin{tabular}{|c|c|}
\hline Varibel & Faktor \\
\hline Aksesibilitas & Aksesibilitas \\
\hline Desain bangunan & Unit apartemen; Prasarana; Sarana; Utilitas \\
\hline Pemeliharaan dan Operasional & Prasarana; Sarana; Utilitas \\
\hline Kualitas Pelayanan & $\begin{array}{c}\text { Reliability; } \text { Assurance; Tangibles; Emphaty; } \\
\text { Responsiveness }\end{array}$ \\
\hline
\end{tabular}

\subsection{Strategi Peningkatan Kepuasan Penghuni}

Salah satu cara untuk memenangkan persaingan adalah menerapkan strategi generik. Secara umum, menurut Porter dalam Umar (1999), strategi generik adalah suatu pendekatan strategi perusahaan dalam rangka mengungguli pesaing dalam industri sejenis. Macam strategi generik menurut Glueck dapat di kategorikan menjadi empat, yaitu: strategi stabilitas (stability), ekspansi (expansion), penciutan (retrenchment), dan kombinasi (combination) dari ketiganya. (Umar, 1999). Dalam menentukan strategi apa yang digunakan dalam meningkatkan kepuasan penghuni, digunakan Important-Performance Analysis (IPA), dimana IPA digunakan untuk mengukur tingkat kepuasan seseorang atas kinerja pihak lain. Kepuasan seseorang tersebut diukur dengan cara membandingkan tingkat harapannya dengan kinerja yang dilakukan pihak lain. Seringkali IPA digunakan oleh perusahaan untuk mengukut kepuasan konsumennya. Analisa IPA didapat dengan tingkat kepentingan dan kepuasan, dan dengan mengunakan kuadran penting - puas (Budianto, 2013).

\section{METODOLOGI PENELITIAN}

Penelitian ini dilakukan dengan menyebarkan kuesioner kepada responden sebanyak 68 responden. Responden adalah penghuni apartemen menengah bawah di Surabaya. eknik sampling pada penelitian ini menggunakan teknik purposive sampling, dimana setiap subjek yang diambil dari populasi dipilih dengan sengaja berdasarkan tujuan dan pertimbangan tertentu. Populasi dalam penelitian ini adalah penghuni apartemen kelas menengah bawah yang memiliki harga unit maksimal Rp. 20 juta per meter persegi (Colliers Internasional, 2016). Sedangkan sesuai dengan klasifikasi apartemen menengah bawah, pada penelitian ini akan mengambil sampel penghuni apartemen menengah bawah, yaitu apartemen dengan harga maksimal Rp. 20 juta per meter persegi (Colliers Internasional, 2016), dengan syarat apartemen tersebut sudah berdiri dan ditempati, dan memenui kesamaan indikator, yaitu memiliki kelengkapan apartemen yang sama antar satu dengan lain nyaData akan dianalisa menggunakan uji t, Anova, serta dengan metode Important-Performance Analysis (IPA).

\section{ANALISIS DAN PEMBAHASAN}

\subsection{Hasil Analisa Deskriptif}

Analisa faktor kepuasan penghuni dilakukan dengan mengumpulkan data - data yang terkait dengan variabel - variabel kepuasan penghuni. Pengumpulan kuesioner dilakukan dengan target responden sebanyak 68 orang, dengan syarat menghuni apartemen menengah bawah di Surabaya. Dari total 68 responden, secara umum penghuni apartemen menengah bawah di Surabaya berjenis kelamin laki - laki $(69,1 \%)$, berpendikikan sarjana $(64,7 \%)$, berusia 16 25 tahun (54,4\%), jumlah penghuni dalam 1 unit sebanyak 2 orang (41.2\%) dan telah menghuni selama $1-3$ tahun $(36,8 \%)$. 


\subsection{Uji Analisa Kesenjangan}

Analisa kesenjangan adalah salah satu metode pengkuran untuk mengetahui kinerja suatu variabel dengan harapan responden terhadap variabel tersebut. Analisis ini merupakan begian dari metode Importance-Performance Analysis. Dalam penelitian ini, digunakan Uji t untuk mengetahui apakah terjadi perbedaan yang berarti antara tingkat kepentingan dan harapan dan kepuasan penghuni apartemen. Uji t dipilih dengan pertimbangan peneliti ingin menguji data yang terkait dalam 1 grup. Nilai uji nantinya akan dianalisa dengan nilai signifikansi $5 \%$, sehingga apabila nilai signifikansi $>0,05$ berarti $\mathrm{HO}$ diterima (tidak ada perbedaan antara antara tingkat harapan penghuni apartemen dengan tingkat kepuasan yang didapat), sedangkan apabila nilai signifikansi $<0,05$ berarti tolak $\mathrm{H} 0$.

Tabel 2. Analisis T-Test Kesenjangan Faktor Kepuasan dan Kepentingan

\begin{tabular}{|c|c|c|c|}
\hline Faktor & $\begin{array}{c}\text { Mean } \\
\text { Difference }\end{array}$ & Sig. & Keterangan \\
\hline Aksesibilitas & 0.62941 & 0.00 & H0 ditolak \\
\hline Desain Bangunan & 0.57996 & 0.00 & H0 ditolak \\
\hline Pemeliharaan dan Operasional & 0.75997 & 0.00 & H0 ditolak \\
\hline Kualitas Pelayanan & 0.64216 & 0.00 & H0 ditolak \\
\hline
\end{tabular}

Berdasarkan Tabel 2, dapat dilihat bahwa seluruh indikator kepuasan terjadi kesenjangan antara tingkat kepuasan dan kepentingan, dimana ditandai dengan nilai signifikansi kurang dari 0.05 serta terdapat perbedaan rata - rata kepuasan dan kepentingan, sehingga dapat disimpulkan bahwa kepuasan penghuni masih belum tercapai.

\subsection{Uji Analisa Anova}

Analysis of Variance adalah salah satu teknik analisis yang berfungsi membedakan mean lebih dari dua kelompok data dengan membandingkan varian nya. Uji anova digunakan untuk mengetahui apakah ada perbedaan antara 2 grup yang berbeda, yaitu kepuasan penghuni dengan lama menghuni. Nilai uji nantinya akan dianalisa dengan nilai signifikansi $5 \%$, sehingga apabila nilai signifikansi $>0,05$ berarti gagal tolak $\mathrm{HO}$ sedangkan apabila nilai signifikansi $<0,05$ berarti tolak $\mathrm{H} 0$, dimana $\mathrm{HO}$ adalah Tidak ada perbedaan tingkat kepuasan antar responden dengan lama menghuni (Tabel 3).

Tabel 3. Analisis Anova Kepuasan Penghuni Berdasarkan Total Kepuasan

\begin{tabular}{|c|c|c|c|c|c|c|c|}
\hline & \multicolumn{2}{|c|}{$1-3$ tahun } & \multicolumn{2}{|c|}{$3-5$ tahun } & \multicolumn{2}{|c|}{$>5$ tahun } & \multirow[b]{2}{*}{ Kesimpulan } \\
\hline & $\begin{array}{c}\text { Mean } \\
\text { Difference }\end{array}$ & Sig. & $\begin{array}{c}\text { Mean } \\
\text { Difference }\end{array}$ & Sig. & $\begin{array}{c}\text { Mean } \\
\text { Difference }\end{array}$ & Sig. & \\
\hline $\begin{array}{c}\leq 1 \\
\text { tahun }\end{array}$ & -.02182 & .929 & -.06417 & .807 & -.38182 & .159 & $\mathrm{H} 0$ gagal ditolak \\
\hline $\begin{array}{c}1-3 \\
\text { tahun }\end{array}$ & - & - & -.04235 & .842 & -.36000 & .107 & $\mathrm{H} 0$ gagal ditolak \\
\hline $\begin{array}{c}3-5 \\
\text { tahun }\end{array}$ & - & - & - & - & -.31765 & .189 & $\mathrm{HO}$ gagal ditolak \\
\hline
\end{tabular}

Dalam penelitian ini, lama menghuni apartemen digolongkan menjadi 4 golongan, yaitu penghuni apartemen yang telah menghuni kurang dari 1 tahun, yang telah menghuni antara 1 tahun hingga 3 tahun, 3 tahun hingga 5 tahun menghuni, serta golongan penghuni yang telah menghuni lebih dri 5 tahun. Secara umum, dapat dilihat pada Tabel 3 bahwa tidak ada perbedaan antara total kepuasan penghuni apartemen dengan lama menghuni. Hal ini ditandai dengan semua dependend variable mendapat nilai signifikan yang tinggi, yaitu diatas 0,05 . 


\subsection{Analisa Importance-Performance Analysis (IPA)}

Anailisis IPA dapat digunakan untuk mengukur tingkat kepuasan seseorang atas kinerja pihak lain dengan menggunakan kuadran penting - puas. Dalam penelitian ini terdapat dua variabel yang diwakili oleh huruf $\mathrm{X}$ dan $\mathrm{Y}$, di mana $\mathrm{X}$ merupakan tingkat kinerja perusahaan (realita) yang dapat memberikan kepuasan para pelanggan, sedangkan $Y$ merupakan tingkat kepentingan yang merupakan harapan pelanggan. Selanjutnya tingkat unsur - unsur tersebut akan dijabarkan dan dibagi menjadi empat kuadran ke dalam diagram kartesius.

$\bullet$ Aksesibilitas $\mathbf{D}$ Desain Bangunan $\mathbf{\Delta}$ Pemeliharaan dan Operasional XKualitas Pelayanan

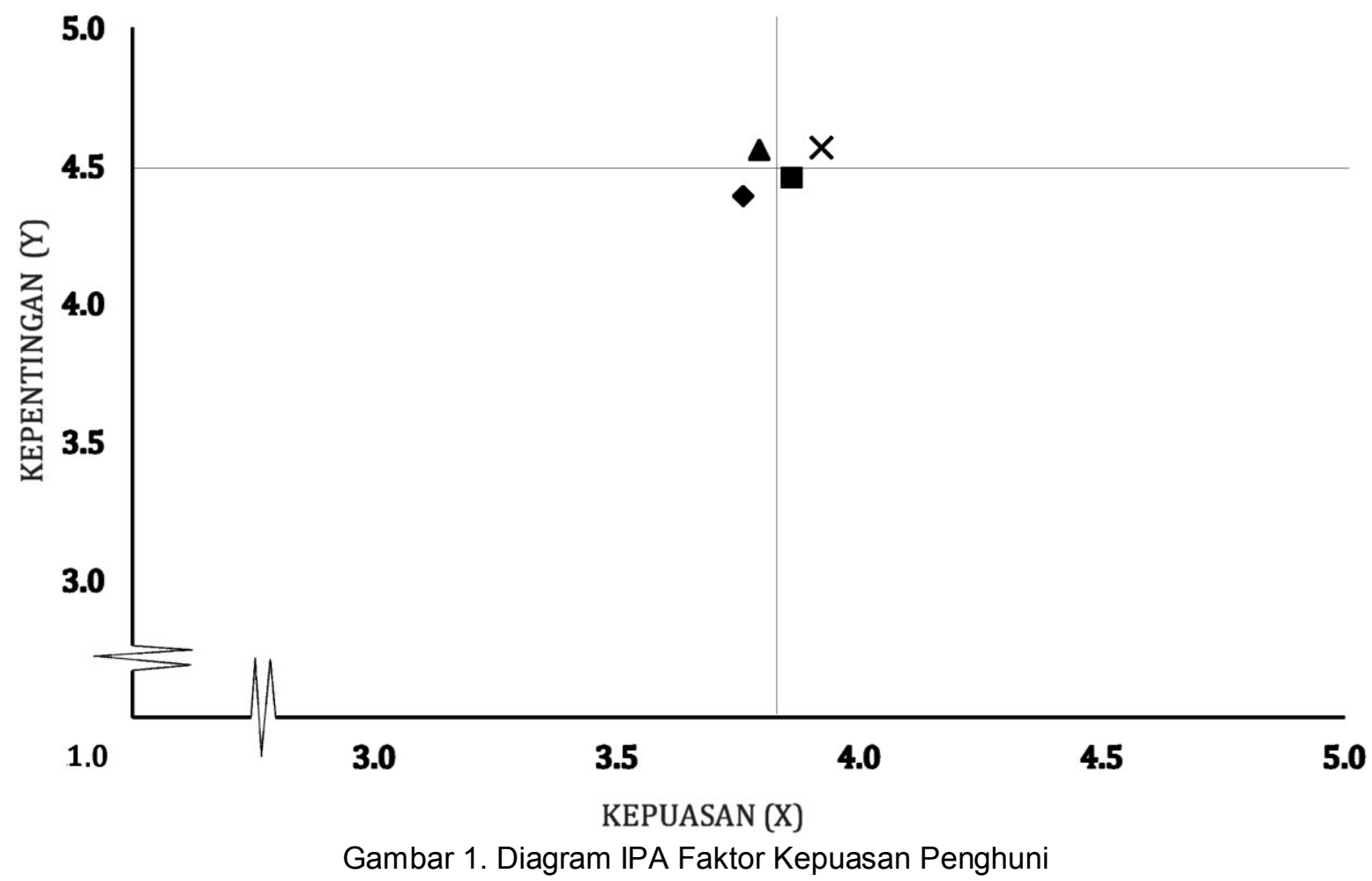

Masing - masing kuadran menunjukkan tingkat prioritas, dimana kuadran I menginterpretasikan Prioritas utama, kuadran II menginterpretasikan Pertahankan Prestasi, kuadran III menginterpretasikan Prioritas Rendah, dan kuadran IV menginterpretasikan Berlebihan Pada perpotongan sumbu X (kepuasan) dan $Y$ (kepentingan) pada Gambar 1 terletak pada 3.83545 pada sumbu $X$ dan sumbu $Y$ pada 4.48325.

Tabel 4. Faktor Kepuasan Penghuni pada Masing - Masing Kuadran

\begin{tabular}{|c|l|c|c|}
\hline Kuadran & \multicolumn{1}{|c|}{ Faktor } & $\mathrm{X}$ (Kepuasan) & Y (Kepentingan) \\
\hline I & Pemeliharaan Dan Operasional & 3.7913 & 4.5513 \\
\hline II & Kualitas Pelayanan & 3.9232 & 4.5654 \\
\hline III & Aksesbilitas & 3.7618 & 4.3912 \\
\hline IV & Desain Bangunan & 3.8655 & 4.4454 \\
\hline
\end{tabular}

Pada Tabel 4 dapat dilihat bahwa faktor pemeliharaan dan operasional termasuk dalam kuadran I,sedangkan faktor kualitas pelayanan termasuk pada kuadranll.Faktor aksesibilitas termasuk dalam kuadran III, dan faktor desain bangunan terletak pada kuadran IV 


\subsection{Strategi Peningkatan Kepuasan Penghuni}

Untuk mencapai kepuasan penghuni, maka diperlukan strategi dalam meningkatkan kepuasan, dimana dapat dilihat pada gambar 1, ke empat faktor dianalisa menggunakan Importance-Performance Analysis, dan didapatkan hasil bahwa faktor pemeliharaan dan operasional masuk dalam kuadran I, yaitu perioritas utama. Hal ini berarti responden memiliki harapan yang tinggi dalam pemeliharaan dan operasional apartemen, namun tingkat kepuasan yang dirasakan lebih rendah dibandingkan harapan responden, sehingga faktor pemeliharaan dan operasional perlu ditingkatkan. Sedangkan faktor kualitas pelayanan masuk kedalam kuadran II, yaitu pertahankan prestasi. Faktor yang berada di kuadran II merupakan faktor yang memiliki tingkat kepentingan / harapan yang tinggi dan tingkat kepuasan yang tinggi juga. Faktor aksesibilitas termasuk dalam kuadran III, yaitu prioritas rendah, dimana faktor aksesibilitas memiliki tingkat kepuasan yang rendah, namun disisi lain juga memiliki tingkat kepentingan / harapan yang rendah. Sebaliknya, faktor desain bangunan termasuk dalam kuadran IV, yatu berlebihan. Hal ini dikarenakan faktor desain bangunan memiliki tingkat kepentingan yang rendah, namun responden cenderung puas terhadap faktor desain bangunan. Pada Tabel 5 dibawah menunjukan ringkasan strategi yang dapat diimplementasikan dalam faktor - faktor kepuasan penghuni.

Tabel 5. Strategi General Glueck

\begin{tabular}{|c|c|c|c|}
\hline Faktor & Kuadran & Strategi Ekspansi & Strategi Stabilitas \\
\hline Aksesibilitas & III & $\sqrt{ }$ & $\sqrt{ }$ \\
\hline Desain Bangunan & IV & & $\sqrt{ }$ \\
\hline Pemeliharaan dan Operasional & I & $\sqrt{ }$ & \\
\hline Kualitas Pelayanan & II & & $\sqrt{ }$ \\
\hline
\end{tabular}

Berdasarkan analisa IPA pada gambar 1, maka pengembang disarankan melakukan strategi general kombinasi yang dikemukakan oleh Umar (1999). Strategi ini diambil karena berdasarkan analisis IPA didapat bahwa faktor - faktor kepuasan tersebar di 4 kuadran.

Strategi ekspansi adalah strategi yang mengutamakan penambahan layanan. Hal ini sesuai dengan faktor yang termasuk dalam kuadran I (prioritas utama), dimana pengembang diharapkan dapat memperbaiki variabel/indikator terkait dengan menambah jasa mapupun menambah fasilitas. Dalam hal ini, faktor yang termasuk dalam kuadran I adalah faktor pemeliharaan dan operasional.

Strategi stabilitas tidak menitikberatkan pada bertambahnya layanan, melainkan hanya meningkatkan layanan yang sudah ada. Hal ini sesuai dengan indikator / variabel dalam kuadran II (pertahankan prestasi) dan IV (berlebihan). Hal ini didasari karena tingkat kepuasan yang sama bahkan melebihi tingkat kepentingan / harapan, sehingga tidak diperlukan penambahan layanan. Faktor - faktor yang termasuk dalam kategori ini adalah faktor desain bangunan dan faktor kualitas pelayanan.

Sedangkan strategi kombinasi adalah campuran dari 2 sampai 3 strategi. Pada penelitian ini, strategi kombinasi dirasa cocok diimplementasikan dalam kuadran III (prioritas rendah), dimana pada prioritas rendah tingkat kepuasan dan kepentingan sama - sama rendah, dimana dengan kondisi ini pengembang memiliki pilihan untuk meningkatkan atau mempertahankan kinerjanya. Strategi kombinasi yang dipakai adalah antara strategi stabilitas dan strategi ekspansi. Faktor yang termasuk dalam kategori ini adalah faktor aksesibilitas. 


\section{KESIMPULAN DAN SARAN}

\subsection{Kesimpulan}

Untuk mengetahui apakah penghuni sudah mencapai kepuasan terhadap apartemen yang telah dihuni, maka dilakukan analisa kesenjangan antara tingkat kepentingan dan kepuasan menggunakan uji t. Hasil uji menunjukkan bahwa terjadi kesenjangan antara tingkat kepuasan dan kepentingan, sehingga kepuasan penghuni belum tercapai. Untuk mengetahui peningkatan kepuasan penghuni apartemen, maka diperlukan data apakah ada perbedaan tingkat kepuasan bedasarkan lama menghuni apartemen. Untuk itu dilakukan uji anova, dan didapat hasil bahwa tidak terjadi perbedaan kepuasan terhadap lama menghuni, sehingga peneliti berasumsi bahwa tidak ada usaha peningkatan kepuasan atau usaha dalam meningkatkan kepuasan tidak berhasil. Oleh karena itu diperlukan strategi dalam peningkatan kepuasan. Dalam hal ini dipilih strategi kombinasi antara strategi ekspansi dan strategi stabilitas. Melalui analisa Importance-Performance Analysis, didapati bahwa faktor pemeliharaan dan operasional termasuk dalam prioritas utama, faktor kualitas pelayanan masuk dalam kuadran pertahankan prestasi, faktor aksesibilitas tergolong prioritas rendah, dan faktor desain bangunan termasuk dalam golongan berlebihan. Bedasarkan hasil uji tersebut maka diperlukan strategi ekspansi, yaitu strategi dengan mengganti maupun menambahkan jasa/produk, dan strategi stabilitas, yaitu strategi dengan meningkatkan efisiensi dan kinerja. Faktor pemeliharaan dan operasional dapat ditingkatkan menggunakan prinsip strategi ekspansi. Sebaliknya, faktor aksesibilitas, desain bangunan dan faktor kualitas pelayanan dapat ditingkatkan menggunakan prinsip strategi stabilitas.

\subsection{Saran}

Bedasarkan hasil analisa IPA dan analisa kesenjangan, terdapat faktor - faktor yang perlu ditingkatkan kinerjanya, dimana dapat dibagi menjadi prioritas utama, pertahankan prestasi, prioritas rendah, serta berlebihan. Diharapkan pegembang dapat mengimplementasikan strategi kombinasi antara strategi ekspansi pada faktor pemeliharaan dan operasional dan faktor aksesibilitas, dan strategi stabilitas pada faktor aksesibilitas, desain bangunan, dan faktor kualitas pelayanan. Untuk proyek - proyek yang akan datang, diharapkan pengembang memperhatikan faktor pemeliharaan dan operasional, dimana masuk kedalam prioritas utama. Bagi perencana bangunan, khususnya arsitek yang bekerja pada bidang bangunan tinggi, diharapkan dapat lebih memperhatikan faktor - faktor yang berpengaruh pada kepuasan penghuni, seperti faktor aksesibilitas, desain bangunan, pemeliharaan dan operasional. Dengan desain yang dapat memenuhi kepuasan penghuni, maka dapat dikatakan proyek tersebut berhasil (Susanto, 2008).

\section{DAFTAR PUSTAKA}

Hadi, A. V. K. dan Hardi, J. (2015). Faktor - Faktor yang Mempengaruhi Kepuasan Penghuni terhadap Desain Bangunan dan Sarana Prasarana di Perumahan Bojong Menteng Indah. (Thesis, Universitas Mercubuana, 2015) Retrieved December 15, 2016 from http://modul.mercubuana.ac.id

Haryanto, R. A. (2013). "Strategi Promosi, Kualitas Produk, Kualitas Layanan terhadap Kepuasan Pelanggan pada Restoran Mcdonalds Manado." Jumal EMBA, 1 (4), 14651473.

Lara, T. dan Bekker, M. C. (2012). "Resident Satisfaction as a Project Quality Measure: The Case of Nova Vida Housing Project, Angola." Journal of Contemporary Management, 9, 364-381.

Prasojo, W. dan Frida, N. (2014). "Analisis Tingkat Kepuasan Penghuni pada Hunian Rumah Susun ditinjau terhadap Kualitas Bangunan di Wilayah Surabaya." Rekayasa Teknik Sipil, 3 (1). Retrieved September 13, 2016, from http://jurnalmahasiswa.unesa.ac.id 
Sari, Y. M. (2007). Evaluasi Kepuasan Penghuni terhadap Atribut Produk Perumahan Telaga Golf di Sawangan, Depok. (Thesis, Universitas Instutut Pertanian Bogor, 2007) Retrieved November 1, 2016 from http://repository.ipb.ac.id

Sutanto, J. A. (2008). "Pengaruh Service Quality dan Percieved Value terhadap Kepuasan dan Loyalitas Konsumen Apartment di Kota Surabaya." Majalah Ekonomi, 18(3), 286301.

Wardani, M. K., Kwanda, T., Raharjo, J. (2001). "Analisis Kepuasan Penghuni Perumahan Sederhana di Denpasar berdasarkan Faktor Lokasi, Prasarana, Sarana, Kualitras Bangunan, Desain, dan Harga." Dimensi Teknik Arsitektur, 29 (2), 117 - 125. 